\title{
Pergerakan Pasukan Untuk Mengejar Musuh Bergerak Menggunakan $D$ * Lite Berbasis Algoritma Pathfinding
}

\author{
Mochamad Kholil \\ Program Studi Sistem Informasi, Fakultas Ilmu Komputer \\ Universitas Nadhlatul Ulama Sidoarjo \\ e-mail: kholil.si@unusida.ac.id
}

\begin{abstract}
Abstrak
Pergerakan agen pada permainan Real Time Strategy dipengaruhi oleh beberapa faktor salah satunya adalah teknik pergerakan agen didalam lingkungan permainan. Pathfinding dalam video game merupakan algoritma kecerdasan buatan bagaimana cara sebuah agen bergerak menemukan jalan optimal dengan usaha minimal sampai pada tujuan. Hal ini bisa dicapai dengan mengimplementasikan suatu algoritma pathfinding pada game. Penelitian ini mengenai algoritma $D^{*}$ Lite yang mampu merencanakan pencarian jalur di lingkungan game dengan environment yang berubah sekaligus objek yang sebagai target bergerak dan menjadikan proses pengejaran target menjadi efisien bagi agen serta memberikan dasar yang kuat untuk penelitian lebih lanjut tentang metode pencarian ulang dalam kecerdasan buatan
\end{abstract}

Kata kunci: Agent Movement, Real Time Strategy, Pathfinding, $D^{*}$ Lite

\begin{abstract}
The movement of agents in the Real Time Strategy game influenced by several factors, one of which is the technique of agent movement within the game environment. Pathfinding in a video game is an artificial intelligence algorithm how to find an agent moves the optimal way in which there are obstacles in the environment. This can be achieved by implementing a pathfinding algorithm to the game. This study of the $D^{*}$ Lite algorithm is able to plan a search path in an game environment, change the environment and moving target to be efficient, optimal and complete for agents and will describe some way of planning applications and provides a solid foundation for further research on methods of search re in artificial intelligence.
\end{abstract}

Keywords: Agent Movement, Real Time Strategy, Pathfinding, $D^{*}$ Lite 